\title{
Determinants of Consumer Intention to Pirate Digital Products
}

\author{
Budi Setiawan $^{1} \&$ Fandy Tjiptono ${ }^{2}$ \\ ${ }^{1}$ Magister of Management Program, Postgraduate Program, Universitas Atma Jaya Yogyakarta, Yogyakarta, \\ Indonesia \\ ${ }^{2}$ Faculty of Economics, Universitas Atma Jaya Yogyakarta, Yogyakarta, Indonesia \\ Correspondence: Fandy Tjiptono, Faculty of Economics, Universitas Atma Jaya Yogyakarta, Yogyakarta, \\ Indonesia. Tel: 62-274-487-711. E-mail: fandy.tjiptono@gmail.com
}

Received: January 12, 2013 Accepted: February 16, 2013 Online Published: April 15, 2013

doi:10.5539/ijms.v5n3p48 URL: http://dx.doi.org/10.5539/ijms.v5n3p48

\begin{abstract}
Digital products, such as software, music, videos, books, and pictures, are vulnerable to digital piracy. The losses caused by pirated digital products have been increasing over years in Indonesia. Long histories of intellectual property rights protection are unable to suppress the piracy behavior. Several studies have been conducted to examine factors affecting consumer intention to pirate digital products. However, a systematic study on consumer intention to commit digital piracy in Indonesia is still limited. The present study aims to address the under-research issue.

The current study is a modified replication of Yoon's (2011) research. Self-administered questionnaires were distributed to 218 students at several universities in Daerah Istimewa Yogyakarta (DIY), Indonesia. Ten research hypotheses were tested using multiple regression analyses. The results indicate that three of the ten hypotheses were not supported, while one hypothesis could not be examined due to its failure to pass a reliability test. Attitude towards digital piracy positively affects consumer intention to commit digital piracy, while moral obligation is a negative predictor of the dependent variable. Subjective norms and perceived behavioral control were found to have insignificant impacts on intention to pirate digital products.
\end{abstract}

Keywords: digital piracy, theory of planned behavior, ethics theory, Indonesia

\section{Introduction}

Consumer ethics has become a growing research of interest for the last two decades. One of the pioneering works in studying ethical issues from the buyer side of the buyer/seller dyad is Vitell and Muncy's (1992) consumer ethics scale. Since the publication of the paper, a number of research has been conducted to investigate consumer ethics in many different contexts (Vitell, 2003). In their further study, Vitell and Muncy (2005) modified the scale and added three new factors. One of them is downloading/buying counterfeit goods. This new factor reflects an emerging concern for the threats of such practices to many industries.

Digital piracy is the practice of copying and/or downloading copyrighted software or digital materials illegally (Al-Rafee \& Cronan, 2006; Cronan \& Al-Rafee, 2008; Yoon, 2011). A study by Business Software Alliance revealed that software piracy rate in Indonesia reached $86 \%$ with estimated loss of US\$ 1.47 billion in 2011 (BSA, 2012). The figures for previous years were $87 \%$ software piracy rate and US\$ 1.32 billion loss (2010), $86 \%$ and US $\$ 0.89$ billion (2009), $85 \%$ and US $\$ 0.54$ billion (2008), and $84 \%$ piracy rate with estimated loss of US\$ 0.41 billion (2007).

Meanwhile, Indonesian music industry has suffered more, where it reported an overall loss of $95 \%$ of the market due to piracy in all forms, i.e. physical, internet, and mobile (IIPA, 2012). Another survey by Political and Economic Risk Consultancy (PERC) found that Indonesia scored worst in Asia in terms of protecting intellectual property rights (www.dailyindonesia.com, accessed on 28 October 2011). Within a score between 0 (the best case) and 10 (the worst case), Indonesia was given a score of 8.50, while Vietnam was the second worst at 8.40, followed by China scored 7.90, the Philippines 6.84, India 6.50, Thailand 6.17 and Malaysia 5.80.

Historically, intellectual property protection is not a new thing in Indonesia. It has been started even long before its independence on 17 August 1945. Copyright acts, for instance, could be traced back to the Dutch colonialization era. The Dutch copyright law, Auteurswet 1912, was put in place in Indonesia until it was 
replaced with the Copyright Act 1982. Under the pressures from the US and European Community (EC) countries, the act was replaced with the Copyright Act 1987 which was more in line with the common practices in Western countries. Later in 2002 a new copyright law was implemented, i.e. Law No. 19 of 2002 on Copyright.

Despite the Indonesian government has shown its commitment and initiated several policies to overcome the counterfeit problems in the country, IIPA (2012) noted that Indonesia remains a market dominated by pirated physical and digital products. The Indonesian government was criticized as failed in addressing online and mobile piracy (IIPA, 2012).

Nevertheless, an understanding of ethical issues requires both sides of perspectives of the buyer/seller dyad (Vitell \& Muncy, 1992). Piracy can take many forms; one of which is digital piracy. A number of studies have investigated this new form of piracy (e.g., Al-Rafee \& Cronan, 2006; Cronan \& Al-Rafee, 2008; Yoon, 2011). However, to date, similar studies in the Indonesian context are still rare. A recent survey by BSA found that 59 percent of computer users in Indonesia admitted they have acquired pirated software, with some users even said they pirated all or most of the time. Therefore, the present study aims to examine determinants of consumer intention to pirate digital products in Indonesia. The main research framework and survey instruments were adapted from Yoon (2011) who integrated theory of planned behavior and ethics theory in his study of Chinese consumer intention to commit digital piracy.

\section{Literature Review and Hypotheses Development}

\subsection{Digital Products and Digital Piracy}

The term 'digital product' refers to any products that can be digitalized, such as software, audio, video, books, and pictures. Such products are very popular in online and mobile businesses since the distribution costs are significantly lower than in conventional distribution. However, digital products are vulnerable to pirate.

Digital piracy is defined as illegal downloading and/or copying of copyrighted digital products, such as software, video, and audio files (Al-Rafee \& Cronan, 2006; Cronan \& Al-Rafee, 2008; Yoon, 2011). Digital products that have been pirated heavily are software (programs, games), audio products (music, recorded speech, tutorials, conversations), video (movies, video clips, recorded concerts, television shows), books (e-books, magazines, journal articles), and pictures (images and photos).

\subsection{Theory of Planned Behavior (TPB)}

The theory of planned behavior (TPB) has been developed to extend the theory of reasoned action (TRA) (Ajzen, 2005). While TRA assumes that consumers consciously evaluate the consequences of alternative behaviors and then select the one that will lead to the most favorable consequences, TPB views that consumers also take account of the ease or difficulty of performing the planned behavior (Blythe, 2008). In TRA, behavioral intention is determined by attitude toward the behavior and subjective norms (Fishbein \& Ajzen, 1975). TPB adds another determinant, i.e. perceived behavioral control (Ajzen, 2005). Therefore, the five main components of the TPB are behavior, behavioral intention, attitude toward the behavior, subjective norms, and perceived behavioral control.

Behavior is a consumer's actions with regard to an attitude object (Solomon, 2009), while behavioral intention is the likelihood that consumers will act a certain way in the future (Schiffman, Kanuk, \& Wisenblit, 2010). Attitude toward the behavior can be defined as a consumer's positive or negative evaluation of performing the behavior in question (Ajzen, 2005). Subjective norm reflects the social pressures the consumer may feel to perform or not to perform the behavior being evaluated (Blythe, 2008). Perceived behavioral control refers to a consumer's perception of whether performing the behavior is or is not within his or her control (Schiffman, et al., 2010).

Previous studies have used TPB to investigate factors affecting piracy behavior. Among them are Peace, Galletta, and Thong (2003), Al-Rafee and Cronan (2006), Cronan and Al-Rafee (2008), Goles, et al. (2008), Morton and Koufteros (2008), Yoon (2011), and Al-Rafee and Dashti (2012).

\subsection{Ethics Theories}

Digital piracy is a major problem facing the technology and creative industries today. It is considered as both illegal and unethical behavior. Therefore, digital piracy has been studied by using Hunt and Vitell's (1986) ethical decision-making theory. The theory holds that individuals are influenced by both deontological (i.e. what is ethical or unethical is defined by rules) and teleological (i.e. consequences of the behavior have to be examined to determine whether it is ethical or not) evaluations (Hunt \& Vitell, 2006). Deontological theories 
comprise moral obligation theory and justice theory. Moral obligation is an individual's feeling of responsibility or personal obligation to do a specific behavior (Cronan \& Al-Rafee, 2008). Justice refers to the treatment of people based on fair rules (Yoon, 2011). Teleological theories focus on perceived consequences, particularly perceived benefits for one's self (egoism) and for the greatest number of people (utilitarianism) (Yoon, 2011).

\subsection{Perceived Benefits, Perceived Risk and Habit}

In addition to the factors related to TPB and ethics theories, three other variables might be significant determinants of consumer attitude toward digital piracy and intention to pirate digital products, i.e. perceived benefits, perceived risk, and habit. Perceived benefits are consumer belief of positive outcomes resulting from pirating a digital product, such as convenience, time saving, and money saving. In contrast, perceived risks are consumer belief in negative consequences of digital piracy behavior, such as punishment certainty and severity (Morton \& Koufteros, 2008; Peace, et al., 2003). Habit refers to past digital piracy behavior. Empirical studies have found that an individual's previous piracy experience influences his or her future piracy intention (Cronan \& Al-Rafee, 2008).

\subsection{Hypotheses Development}

Yoon (2011) proposed and empirically tested an integrated model of TPB and ethics theory to investigate consumer intention to pirate digital products (refer to Figure 1). Four variables (subjective norm, attitude toward digital piracy, perceived behavioral control, and intention to pirate digital products) represent the theory of planned behavior perspective. Four other variables (moral obligation, justice, perceived benefit, and perceived risk) are based on ethics theories. The last variable, habit, is postulated to influence consumer attitude toward digital piracy.

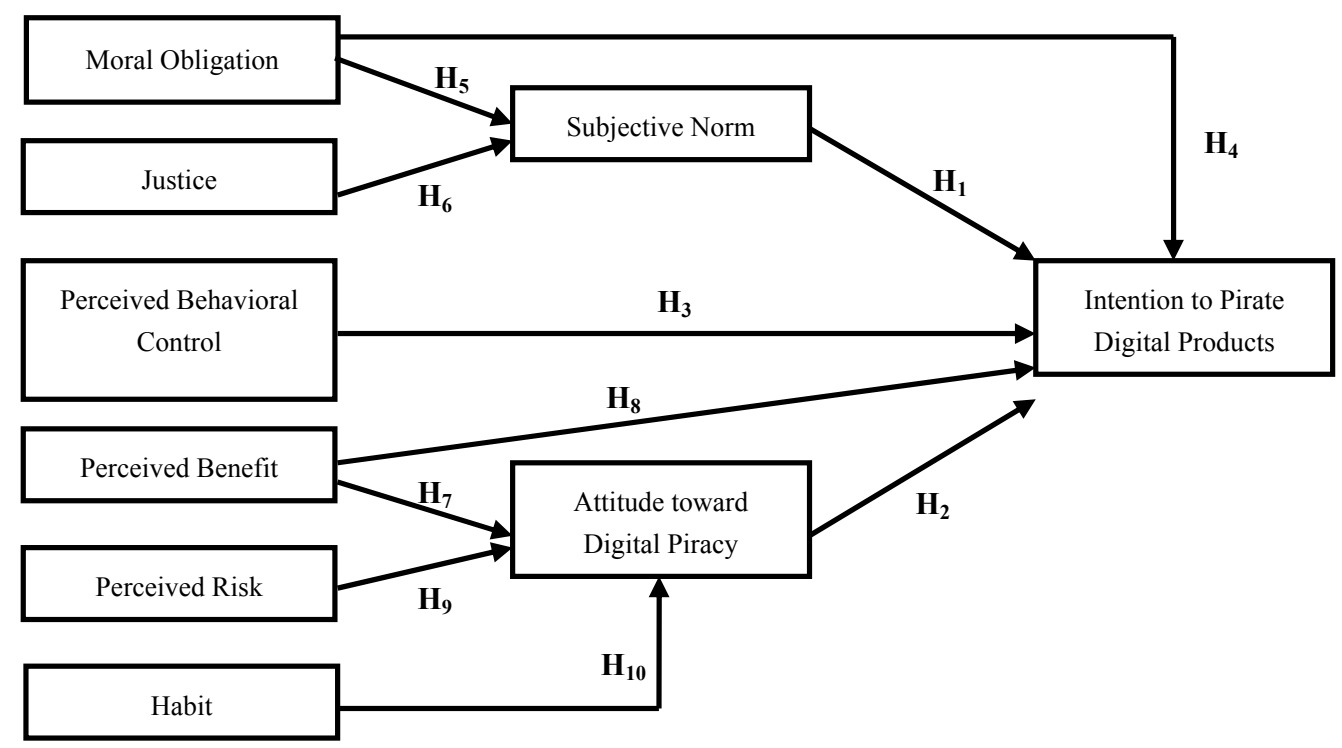

Figure 1. The research framework

Source: Yoon (2011).

Theory of planned behavior states that a specific behavior is influenced by the behavioral intention, which is explained by attitude toward the behavior, subjective norm, and perceived behavioral control. In their study of software piracy in the workplace, Peace, et al. (2003) found empirical support for positive impacts of attitude, subjective norm, and perceived behavioral control on intention to illegally copy software. Another research by Morton and Koufteros (2008) also concluded that attitude toward piracy, subjective norm, and perceived behavioral control are significant predictors of intention to pirate online music products. Similar findings were also reported in Yoon's (2011) study of digital piracy in China. Therefore, hypothesis 1,2 and 3 can be postulated as follows:

$\mathrm{H}_{1}$ : Subjective norms toward digital piracy have a positive effect on consumer intention to pirate digital products.

$\mathrm{H}_{2}$ : Attitude toward digital piracy has a positive effect on consumer intention to pirate digital products.

$\mathrm{H}_{3}$ : Perceived behavioral control has a positive effect on consumer intention to pirate digital products. 
In 1967, Fishbein included a moral value component along with attitude and subjective norms to predict behavioral intention (Ajzen, 2005). Moral obligation was removed on a later research, because Fishbein and Ajzen thought that moral is an alternative method to measure behavioral intention (Ajzen, 2005). Ajzen (2005) states that moral obligation would be expected to influence behavioral intention, together with attitudes, subjective (social) norms, and perceived behavioral control in the context of unethical behavior. Despite being removed from the TPB model, moral obligation has been reintroduced as an antecedent of behavioral intention. Cronan and Al-Rafee (2008), for example, found that moral obligation is a significant negative determinant of intention to pirate digital materials. Moral obligation was found to have a negative effect on both subjective norm and behavioral intention in Yoon's (2011) study. Hence, hypothesis 4 and 5 can be formulated as follows:

$\mathrm{H}_{4}$ : Moral obligation has a negative effect on consumer intention to pirate digital products.

$\mathrm{H}_{5}$ : Moral obligation has a negative effect on subjective norms toward digital piracy.

Justice is about equality and fairness. It provides a standard of ethics in judging what is right and wrong. Yoon (2011) hypothesized and found an empirical support for a negative effect of justice on subjective norms. He argued that his respondents regarded digital piracy as an unfair and unethical behavior. Thus, hypothesis 6 can be stated as follows:

$\mathrm{H}_{6}$ : Justice has a negative effect on subjective norms toward digital piracy.

Goles, et al. (2008) concluded that the greater an individual perceives the benefits or usefulness of illegal duplication of copyrighted software, the more favorable his or her attitude is toward the unethical practice. Furthermore, Yoon (2011) found that perceived benefit positively affects both attitude toward digital piracy and intention to commit digital piracy.

On the contrary, perceived risk was found to have a negative effect on software piracy (Peace, et al., 2003). As the chances of being caught and the level of punishment (e.g., a heavy fine or being arrested) increase, an individual's attitude toward software piracy will become less positive. In the digital piracy case, Yoon (2011) reported that perceived risk has a negative impact on consumer attitude toward digital piracy. As a result, hypothesis 7,8 , and 9 are formulated as follows:

$\mathrm{H}_{7}$ : Perceived benefit has a positive effect on consumer attitude toward digital piracy.

$\mathrm{H}_{8}$ : Perceived benefit has a positive effect on consumer intention to pirate digital products.

$\mathrm{H}_{9}$ : Perceived risk has a negative effect on consumer attitude toward digital piracy.

Goles, et al. (2008) reported that past softlifting behavior is positively related with future softlifting behavioral intention. They distinguished three types of piracy behavior: commercial piracy (for resale purposes), corporate piracy (for use within an organization), and softlifting (for personal usage). Softlift is defined as the illegal copying and/or downloading of copyrighted software by individuals for personal usage (Goles, et al., 2008). In his study, Yoon (2011) found support for a significant positive impact of habit on consumer attitude toward digital piracy. Consequently, hypothesis 10 can be proposed as follows:

$\mathrm{H}_{10}$ : Habit has a positive effect on consumer attitude toward digital piracy.

\section{Research Method}

\subsection{Research Context}

A survey using self-administered questionnaires was conducted to examine determinants of consumer intention to pirate digital products in Indonesia. A convenient sample of 280 undergraduate students in Daerah Istimewa Yogyakarta (DIY) was selected to address the research question of interest. Students were used as the sample for two main reasons. First, a high proportion of students have shown to commit piracy behavior (Gopal \& Sanders, 2000; Sims \& Cheng, 1996). Second, student samples have been considered as adequate and representative as well as have been used in ethics literature to investigate software and online music piracy (Al-Rafee \& Cronan, 2006; Kuo \& Hsu, 2001; Morton \& Koufteros, 2008; Wagner \& Sanders, 2001). Al-Rafee and Cronan (2006) argue that student samples have been assumed to be suitable surrogates for business managers and decision makers, especially in the ethical decision-making process study.

\subsection{Measures}

All measures used for the present survey were adapted from Yoon (2011). The questionnaires were carefully translated from the original English version into Bahasa Indonesia, double-checked, and pre-tested before being used in the main survey. A five-point scale was used to measure nine variables: subjective norms (4 items), attitude toward digital piracy (4 items), perceived behavioral control (4 items), intention to pirate digital products 
(3 items), moral obligation ( 3 items), justice ( 2 items), perceived benefit (4 items), perceived risk ( 3 items), and habit (4 items). All items of subjective norms and an item of intention to pirate digital products are reversed items that were coded and treated accordingly.

\section{Results}

\subsection{Validity and Reliability of the Measures}

There were 280 questionnaires distributed at five major public and private universities in the Daerah Istimewa Yogyakarta (Indonesia). However, only 218 of them (56\% male and $44 \%$ female) were returned and complete (a response rate of $77.86 \%$ ). Pearson product moment coefficient of correlation and Cronbach's alpha were used to test the validity and reliability of the multiple-item measures in the present study. Perceived behavioral control was found to be unreliable since the Cronbach's alpha was only 0.442 . Even if any items of the variable were deleted, the Cronbach's alpha could not be improved. As a result, perceived behavioral control was dropped from further analyses. In addition, an item of perceived benefit was found to be invalid; therefore, it was also eliminated. Table 1 shows the intercorrelations of the final scales used for the present study and summary information.

Table 1. Construct intercorrelations and reliability

\begin{tabular}{lcccccccc}
\hline & $\mathbf{1}$ & $\mathbf{2}$ & $\mathbf{3}$ & $\mathbf{4}$ & $\mathbf{5}$ & $\mathbf{6}$ & $\mathbf{7}$ & $\mathbf{8}$ \\
\hline 1. Subjective Norm & 1 & & & & & & & \\
2. Attitude toward & $0.432^{* *}$ & 1 & & & & & & \\
Piracy & & & & & & & \\
3. Intention to Pirate & $0.271^{* *}$ & $0.378^{* *}$ & 1 & & & & & \\
4. Moral Obligation & $-0.370^{* *}$ & $-0.528^{* *}$ & $-0.356^{* *}$ & 1 & & & & \\
5. Justice & 0.022 & -0.069 & $0.174^{* *}$ & 0.034 & 1 & & & \\
6. Perceived Benefit & $0.226^{* *}$ & $0.487^{* *}$ & $0.261^{* *}$ & $-0.309^{* *}$ & -0.062 & 1 & & \\
7. Perceived Risk & $-0.200^{* *}$ & $-0.430^{* *}$ & $-0.180^{* *}$ & $0.349^{* *}$ & $0.191^{* *}$ & $-0.210^{* *}$ & 1 & \\
8. Habit & $0.285^{* *}$ & $0.343^{* *}$ & $0.662^{* *}$ & $-0.314^{* *}$ & $0.161^{*}$ & $0.181^{* *}$ & $-0.169^{*}$ & 1 \\
Cronbach's Alpha & 0.893 & 0.848 & 0.675 & 0.821 & 0.980 & 0.755 & 0.925 & 0.904 \\
Number of Items & 4 & 4 & 3 & 3 & 2 & 3 & 3 & 4 \\
Mean & 3.88 & 3.80 & 3.37 & 2.13 & 3.80 & 4.24 & 3.06 & 3.00 \\
Standard Deviation & 0.48 & 0.63 & 0.64 & 0.34 & 0.59 & 0.38 & 0.71 & 0.73 \\
\hline
\end{tabular}

Note: ${ }^{* *}$ Correlation is significant at the 0.01 level $(2$-tailed); $*$ correlation is significant at the 0.05 level (2-tailed).

Source: Primary data (processed).

\subsection{Determinants of Consumer Intention to Pirate Digital Products}

Three multiple regression analyses were employed to test the research hypotheses. Table 2 summarizes the results. Attitude toward digital piracy $(\beta=0.193 ; \rho=0.020)$ and moral obligation $(\beta=-0.192 ; \rho=0.010)$ were found to be significant predictors of consumer intention to pirate digital products. Subjective norms and perceived benefit did not significantly affect the digital piracy intention. Thus, $\mathrm{H}_{2}$ and $\mathrm{H}_{4}$ were supported, while $\mathrm{H}_{1}$ and $\mathrm{H}_{8}$ were not supported. $\mathrm{H}_{3}$ (the positive effect of perceived behavioral control (PBC) on intention to pirate digital products) could not be examined due to the reliability issue of the $\mathrm{PBC}$ scale.

As predicted by $\mathrm{H}_{5}$, a significant negative effect was found $(\beta=-0.372 ; \rho=0.000)$. It suggests that high moral obligation is associated with low subjective norms toward digital piracy, and vice versa. However, no significant effect of justice on subjective norm was found $(\beta=0.035 ; \rho=0.579)$. As a result, $\mathrm{H}_{6}$ was not supported.

Consistent with $\mathrm{H}_{7}, \mathrm{H}_{9}$, and $\mathrm{H}_{10}$, the current research has found that perceived benefit $(\beta=0.382 ; \rho=0.000)$, perceived risk $(\beta=-0.312 ; \rho=0.000)$, and habit $(\beta=0.222 ; \rho=0.000)$ are significant determinants of consumer attitude toward digital piracy.

Table 3 presents the summary of hypothesis testing results. Overall, six of the ten hypotheses were supported (i.e. $\mathrm{H}_{2}, \mathrm{H}_{4}, \mathrm{H}_{5}, \mathrm{H}_{7}, \mathrm{H}_{9}$, and $\mathrm{H}_{10}$ ) while one of them could not be examined (i.e. $\mathrm{H}_{3}$ ). 
Table 2. Determinants of intention to pirate digital products, subjective norm, and attitude toward digital piracy

\begin{tabular}{|c|c|c|c|c|c|c|c|}
\hline \multirow{2}{*}{$\begin{array}{c}\text { Dependent } \\
\text { Variable }\end{array}$} & \multirow{2}{*}{ Independent Variable } & \multirow{2}{*}{$\begin{array}{c}\text { Standardized } \\
\text { Beta }\end{array}$} & \multicolumn{2}{|c|}{$\mathbf{t}$} & \multirow{2}{*}{$\begin{array}{l}\text { Adj. } R \\
\text { Square }\end{array}$} & \multicolumn{2}{|c|}{$\mathbf{F}$} \\
\hline & & & Value & Sig. & & Value & Sig. \\
\hline Inten & Subjective Norm & 0.097 & 1.396 & 0.164 & & & \\
\hline Pirate Digital & Attitude toward Piracy & 0.1 & 2.339 & $0.020^{*}$ & .175 & 12.473 & $0.000^{* *}$ \\
\hline Products & $\begin{array}{l}\text { Moral Obligation } \\
\text { Perceived Benefit }\end{array}$ & & $\begin{array}{c}-2.589 \\
1.211\end{array}$ & $\begin{array}{c}0.010^{* *} \\
0.227\end{array}$ & & & \\
\hline $\begin{array}{l}\text { Subjective } \\
\text { Norm }\end{array}$ & $\begin{array}{l}\text { Moral Obligation } \\
\text { Justice }\end{array}$ & & $\begin{array}{c}-5.870 \\
0.556\end{array}$ & $\begin{array}{c}0.000 * * \\
0.579\end{array}$ & 0.131 & 17.289 & $0.000^{* *}$ \\
\hline $\begin{array}{l}\text { Attitude toward } \\
\text { Digital Piracy }\end{array}$ & $\begin{array}{l}\text { Perceived Benefit } \\
\text { Perceived Risk } \\
\text { Habit }\end{array}$ & $\begin{array}{c}0.382 \\
-0.312 \\
0.222\end{array}$ & $\begin{array}{c}6.947 \\
-5.697 \\
4.065\end{array}$ & $\begin{array}{l}0.000^{* *} \\
0.000 * * \\
0.000 * *\end{array}$ & 0.388 & 46.812 & $0.000^{* *}$ \\
\hline
\end{tabular}

Note: ** Significant at the 0.01 level (2-tailed); * Significant at the 0.05 level (2-tailed).

Source: Primary data (processed).

Table 3. A summary of hypothesis testing results

\begin{tabular}{|c|c|c|}
\hline & Hypothesis & Conclusion \\
\hline $\mathrm{H}_{1}$ & $\begin{array}{l}\text { Subjective norms toward digital piracy have a positive effect on consumer } \\
\text { intention to pirate digital products. }\end{array}$ & Not Supported \\
\hline $\mathrm{H}_{2}$ & $\begin{array}{l}\text { Attitude toward digital piracy has a positive effect on consumer intention to } \\
\text { pirate digital products. }\end{array}$ & Supported \\
\hline $\mathrm{H}_{3}$ & $\begin{array}{l}\text { Perceived behavioral control has a positive effect on consumer intention to } \\
\text { pirate digital products. }\end{array}$ & $\begin{array}{l}\text { Could not be } \\
\text { examined }\end{array}$ \\
\hline $\mathrm{H}_{4}$ & $\begin{array}{l}\text { Moral obligation has a negative effect on consumer intention to pirate digital } \\
\text { products. }\end{array}$ & Supported \\
\hline $\mathrm{H}_{5}$ & $\begin{array}{l}\text { Moral obligation has a negative effect on subjective norms toward digital } \\
\text { piracy. }\end{array}$ & Supported \\
\hline $\mathrm{H}_{6}$ & Justice has a negative effect on subjective norms toward digital piracy. & Not Supported \\
\hline $\mathrm{H}_{7}$ & $\begin{array}{l}\text { Perceived benefit has a positive effect on consumer attitude toward digital } \\
\text { piracy. }\end{array}$ & Supported \\
\hline $\mathrm{H}_{8}$ & $\begin{array}{l}\text { Perceived benefit has a positive effect on consumer intention to pirate digital } \\
\text { products. }\end{array}$ & Not Supported \\
\hline $\mathrm{H}_{9}$ & Perceived risk has a negative effect on consumer attitude toward digital piracy. & Sup! \\
\hline $\mathrm{H}_{10}$ & Habit has a negative effect on consumer attitude toward digital piracy. & Supported \\
\hline
\end{tabular}

\section{Discussions}

In comparison with Yoon's (2011) study, the present research found empirical support only for six of the ten hypotheses. The determinants of consumer intention to pirate digital products are attitude toward digital piracy and moral obligation. The more positive/favorable the attitude toward digital piracy, the more likely an individual commits the act, and vice versa. On the 5-point Likert scale, the mean scores for all attitude items were 3.78 ("digital piracy is a foolish/wise idea"), 4.06 (harmful/beneficial idea), 3.65 (bad/good idea), and 3.71 (unfavorable/favorable). It suggests that students in Daerah Istimewa Yogyakarta (DIY, Indonesia) tend to have a somewhat positive attitude toward digital piracy.

Furthermore, moral obligation was found to negatively affect consumer intention to pirate digital products. However, the mean scores for the three items of moral obligation were 2.11 ("I would feel guilty if I pirated digital products"), 2.09 ("To pirate digital products goes against my principles"), and 2.18 ("It would be morally wrong for me to pirate digital products"). It suggests that students in DIY do not feel guilty when they committed digital piracy.

The current study suggests that the predictor for subjective norm is moral obligation. Those who considered digital piracy as a morally wrong conduct would feel a social pressure to avoid digital piracy. Meanwhile, the antecedents of attitude toward digital piracy consist of perceived benefit, perceived risk, and habit. Perceived benefit is the strongest predictor of attitude toward digital piracy. If an individual finds digital piracy beneficial, then he/she will have a positive attitude towards the piracy, and vice versa. Perceived risk has a negative effect 
on attitude toward digital piracy, while habit positively affects the dependent variable. The overall mean scores for perceived benefit, perceived cost, and habit were 4.24; 3.06; and 2.99, respectively. It suggests that students in DIY perceived that digital piracy has several benefits (i.e. save money, save time, and possess more digital products); does not have a high risk (e.g., a chance to be caught, be arrested, or be heavily penalized); and has not been a habit for them.

\section{Conclusions and Implications}

\subsection{Conclusion}

In his study of digital piracy in China, Yoon (2011, p. 415) recommended, "the study should be conducted in other countries". The present study is a response to the call for research. Overall, it is found that the integration of theory of planned behavior and ethics theory can provide a better understanding of the digital piracy phenomenon. The current research also provides empirical support for six of the ten hypotheses developed in Yoon (2011).

\subsection{Implications}

Attitudes toward digital piracy and moral obligation are the two significant determinants of consumer intention to pirate digital products. The main concern for combating digital piracy in Indonesia is that there was a positive attitude and low level of guilt (moral obligation) towards digital piracy. It requires integrated efforts of all relevant parties, such as government, industry players, educators, and general public. Law enforcement and stricter ethical codes of conduct in regards to intellectual property rights protection have to be consistently implemented. When applied, this will contribute to the development of negative attitudes (via lower perceived benefits, higher perceived risks, and less piracy experiences) and high levels of guilt towards digital piracy among consumers, which in turn will reduce their intention to pirate digital products.

Despite its potential contributions, the present study has some limitations, such as the issue of generalizability due to its sampling method used (i.e. convenience sampling), narrow range of population (i.e. student sample), limited number of samples, limited geographical scope (i.e. Daerah Istimewa Yogyakarta), analytical tools (i.e. multiple regressions instead of structural equation modeling), and research methods (i.e. survey instead of experiments). Further research could be designed to minimize these weaknesses.

\section{References}

Ajzen, I. (2005). Attitudes, personality, and behavior (2nd ed.). Berkshire: Open University Press and McGraw-Hill.

Al-Rafee, S., \& Dashti, A. E. (2012). A cross cultural comparison of the extended TPB: The case of digital piracy. Journal of Global Information Technology Management, 15(1), 5-24.

Anonymous. (2012). Indonesia No. 1 in copyright piracy in Asia. Retrieved from http://www.dailyindonesia.com/news/top/2010/08/indonesia-no1-in-copyright-piracy-in-asia.php

Blythe, J. (2008). Consumer behaviour. London: Thomson Learning.

BSA. (2011). 2011 global software piracy study. Business Software Alliance News Release, May 12.

BSA. (2011). Values of PC software theft in Indonesia reach record high of US\$ 1.32 billion. Business Software Alliance News Release, May 12.

BSA. (2012). BSA report finds 59 percent of computer users in Indonesia admit they pirate software. Business Software Alliance News Release, May 15.

Cronan, T. P., \& Al-Rafee, S. (2008). Factors that influence the intention to pirate software and media. Journal of Business Ethics, 78, 527-545. http://dx.doi.org/10.1007/s10551-007-9366-8

Fishbein, M., \& Ajzen, I. (1975). Belief, attitude, intention, and behavior: An introduction to theory and research. New York: Addison-Wesley Publishing Company, Inc.

Goles, T. et al. (2008). Softlifting: Exploring determinants of attitude. Journal of Business Ethics, 77, 481-499. http://dx.doi.org/10.1007/s10551-007-9361-0

Gopal, R. D., \& Sanders, G. L. (2000). Global software piracy: You can't get blood out of a turnip. Communications of the ACM, 43(10), 83-89.

Hunt, S. D., \& Vitell, S. J. (1986). A general theory of marketing ethics. Journal of Macromarketing, 6(5), 5-16. http://dx.doi.org/10.1177/027614678600600103

Hunt, S. D., \& Vitell, S. J. (2006). A general theory of marketing ethics: A revision and three questions. Journal 
of Macromarketing, 26(2), 1-11. http://dx.doi.org/10.1177/0276146706290923

International Intellectual Property Alliance (IIPA). (2012). Indonesia: 2012 special 301 report in copyright protection and enforcement. 2012 Special 301: Indonesia, February 10, 79-90.

Kuo, F., \& Hsu, M. (2001). Development and Validation of Ethical Computer Self-Efficacy Measure: The Case of Softlifting. Journal of Business Ethics, 32, 299-315. http://dx.doi.org/10.1023/A:1010715504824

Morton, N. A., \& Koufteros, X. (2008). Intention to commit online music piracy and its antecedents: An empirical investigation. Structural Equation Modeling, 15, 491-512. http://dx.doi.org/10.1080/10705510802154331

Peace, A. G., Galletta, D. F., \& Thong, J. Y. L. (2003). Software piracy in the workplace: A model and empirical test. Journal of Management Information System, 20(1), 153-177.

Schiffman, L. G., Kanuk, L. L., \& Wisenblit, J. (2010). Consumer behavior (10th ed.). New Jersey: Pearson Education, Inc.

Sims, R., \& Cheng, H. (1996). Toward a profile of student software piraters. Journal of Business Ethics, 15, 839-849. http://dx.doi.org/10.1007/BF00381852

Solomon, M. R. (2009). Consumer behavior: Buying, having, and being (8th ed.). New Jersey: Pearson Education, Inc.

Vitell, S. J. (2003). Consumer ethics research: Review, synthesis and suggestions for the future. Journal of Business Ethics, 43(1/2), 33-47. http://dx.doi.org/10.1023/A:1022907014295

Vitell, S. J., \& Muncy, J. (1992). Consumer ethics: An empirical investigation of factors influencing ethical judgments of the final consumer. Journal of Business Ethics, 11(8), 585-597. http://dx.doi.org/10.1007/BF00872270

Vitell, S. J., \& Muncy, J. (2005). The Muncy-Vitell consumer ethics scale: A modification and application. Journal of Business Ethics, 62, 267-275. http://dx.doi.org/10.1007/s10551-005-7058-9

Wagner, S., \& Sanders, G. (2001). Considerations in ethical decision-making and software piracy. Journal of Business Ethics, 29(1/2), 161-167. http://dx.doi.org/10.1023/A:1006415514200

Yoon, C. (2011). Theory of planned behavior and ethics theory in digital piracy: An integrated model. Journal of Business Ethics, 100, 405-417. http://dx.doi.org/10.1007/s10551-010-0687-7 